\section{Главный редактор:}

А. Ф. Туманян - д. С.-х. н., проф.

\section{Редакционный совет:}

Н. Н. Дубенок, академик РАН, д.с.-х.н., профр.; В. М. Косолапов - академик РАН, д.с.-х.Н., проф.; А. Л. Иванов академик РАН, д.б.Н., проф.; К. Н. Кулик - академик РАН, д.С.-Х.Н., проф.; В. Г. Плющиков - д.с.-Х.Н., проф.; В. П. Зволинский - академик РАН, д.с.-х.н., профр.; Ш. Б. Байрамбеков д.с.-х.н., проф., заслуженный агроном РФ; С. Р. Аллахвердиев - академик PAE, д.б.н., профр.; С. Н. Еланский д.б.н.; М. М. Оконов - член-корр. РАЕН, д.с.-Х.н., проф.; В. Ф. Пивоваров - академик РАН, д.с.-х.Н., проф.; П. Ф. Кононков - академик АНИРР, д.С.-Х.Н., проф.; Ю. В. Трунов - д.С.-х.н., проф.; М. С. Гинс - член-корреспондент РАН, д.б.н., профр.; Н. В. Тютюма - д.С.-х.н., профр. РАН; А. Н. Арилов - д.С.-Х.Н., профр.; Ю. А. Ватников - д.В.Н., профр.; Н. В. Донкова - д.В.н., профр.; Т. С. Кубатбеков - д.б.н., доцент; Е. М. Ленченко - д.В.Н., профр.; В. Е. Никитченко - д.В.Н., проф.; Н. Н. Балашова д.э.н., профр.; В. М. Пизенгольц - д.э.Н., проф.; В. С. Семенович - д.э.н., профр.; Н. Н. Скитер - д.э.Н., профр.; Р. С. Шепитько - д.э.н., проф.; Т. В. Папаскири - д.э.н., профр.

\section{Head editor:}

A. F. Tumanyan - Dr. Agr. Sci., Prof.

\section{Editorial Board:}

N. N. Dubenok, RAS memb., V. M. Kosolapov - RAS memb.; A. L. Ivanov - RAS memb.; K. N. Kulik - RAS memb.; V. G. Plyushchikov - Dr.Sc.agr.; V. P. Zvolinskij - RAS memb.; SH. B. Bajrambekov Dr.Sc.agr.; S. R. Allahverdiev-RANmemb.; S. N. Elanskij - Dr.Sc.biol.; M. M. Okonov RAEN cor.m.; V. F. Pivovarov - RAS memb.; P. F. Kononkov - ANIRR memb.; Yu. V. Trunov - Dr.Sc.agr.; M. S. Gins RAS cor.m.; N. V. Tyutyuma - Dr.Sc.agr.; A. N. Arilov - Dr.Sc.agr.; Yu. A. Vatnikov Dr.Sc.vet.; N. V. Donkova - Dr.Sc. vet.; T. S. Kubatbekov - Dr.Sc.biol.; E. M. Lenchenko - Dr.Sc.vet.; V. E. Nikitchenko - Dr.Sc.vet.; N. N. Balashova Dr.Sc.econ.; V. M. Pizengol'c - Dr.Sc. econ.; V. S. Semenovich - Dr.Sc.econ.; N. N. Skiter - Dr.Sc.econ.; R. S. SHepit'ko - Dr.Sc.econ.; T. V. Papaskiri Dr.Sc.econ.

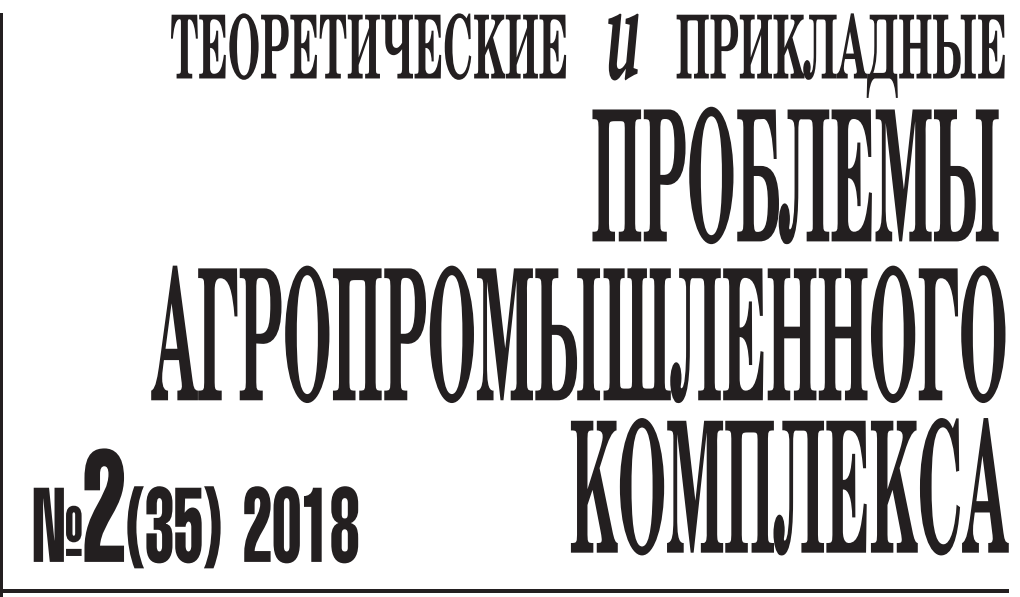

\section{Содержание}

\section{0бщее земледелие, растениеводство}

Ш. Б. Байрамбеков, Г. В. Гуляева,

Е. Д. Гарьянова, М. А. Долгов

Влияние элементов технологии возделывания

кочанного салата в Астраханской области

на урожайность и качество. 3

\section{С. А. Корнацкий, А. А. Попкова, А. Ж. Семенов}

Опыт использования рассады картофеля

при выращивании миниклубней в теплице .... .7

\section{М. Ю. Пучков, В. В. Зволинский, Е. Г. Локтионова}

Влияние сроков посева

на урожайность лука репчатого.

\section{Н. В. Тютюма, И. И. Климова, Н. А. Наумова,}

В. А. Федорова, Ю. П. Тарасенкова

Влияние биоприпаратов на продуктивность

ярового ячменя в почвенно-климатических условиях

Северного Прикаспия .17

\section{Ветеринария}

\section{В. Д. Родионов, Ю. А. Ватников, И. Ф. Вилковыский}

Диагностика эритроцитарных нарушений

при остром гепатите у собак. 


\section{Редактор}

О. В. Любименко

\section{Оформление и верстка}

\author{
В. В. Земсков
}

\section{Адрес редакции: \\ 111116, Москва, \\ ул. Авиамоторная, 6, тел./факс: (499) 507-80-45, \\ e-mail: agrobio@list.ru. \\ Интернет: http://www.nitu.ru \\ При перепечатке любых материалов ссылка на журнал «Теоретические и прикладные проблемы агропромышленного комплекса» обязательна.}

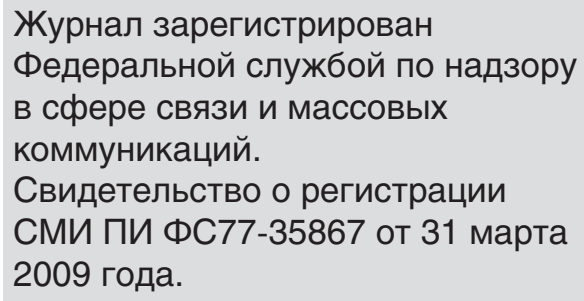

\section{ISSN 2221-7312}

Включен в перечень изданий Высшей аттестационной комиссии Министерства образования и науки РФ

\section{Формат $60 \times 841 / 8$}

Тираж 1000 экз.

Редакция не несет ответственности за достоверность информации в материалах, в том числе рекламных, предоставленных авторами для публикации. Материалы авторов не возвращаются.

Отпечатано в ООО ИПФ «СТРИНГ» 424006, Республика Марий Эл,

г. Йошкар-Ола, ул. Строителей, 95
Бинхун Ху, Ю. А. Ватников, Е. В. Куликов,

И. А. Попова, О. А. Петрухина

Лечение гнойного эндометрита у собак

\section{Микробиология}

К. А. Коледенкова, М. М. Романеи, Е. В. Романова

Сравнительный анализ чувствительности возбудителя снежной плесени Microdochium Nivale

к действующим веществам различных классов

\section{Экология}

И. Н. Воробьева, Е. Ю. Зайкова

Разработка новых методов ландшафтной архитектуры и концепция их интеграции в туристические маршруты, на примере водных маршрутов г. Санкт-Петербург

\section{Экономика и управление народным хозяйством}

\section{В. Ю. Чернова}

Экспортоориентированное импортозамещение

в пищевой промышленности как элемент

углубления интеграции в рамках ЕАЭС

\section{A. 3. Улимбашев}

Типологизация субъектов малого бизнеса

в сельском хозяйстве

Гринсон Годдэй Нгерибо, Илебери Вариеби

Современные проблемы аграрной экономики

\section{Рыбное хозяйство}

П. Е. Гарлов, Н. Б. Рыбалова, Т. А. Нечаева,

С. У. Темирова, Е. Д. Шинкаревич, Б. С. Бугримов

Разработка новых методов биотехники воспроизводства рыб на основе анализа механизмов нейроэндокринной регуляции их размножения..... 
Влияние элементов технологии воздельвания кочанного салата в Астраханской области на урожайность и качество

Ш. Б. Байрамбеков ${ }^{1}$ (д.с.-Х.н.), Г. В. Гуляева ${ }^{1}$ (к.с.-х.н.), Е. Д. Гарьянова ${ }^{1}$ (к.с.-х.н.), М. А. Долгов ${ }^{2}$

${ }^{1}$ Всероссийский НИИ орошаемого овощеводства и бахчеводства,

${ }^{2}$ Филиал ФГБУ «Российский сельскохозяйственный центр» по Астраханской области, vniiob-100@mail.ru

Посевные площуад, занятые под салатом в Астраханской области, незначительны, но имеется значительный потенциил увеличения производства этой культуры. Актуальным является увеличение валовых сборов салата из открытого грунта в ранние сроки. Наиболее ранний урожай высококачественной продукиии кочанного салата можно получить, высаживая рассаду под временные укрытия из нетканого укрывного материала. Проведенные исследования показали, что под временньми укрытиями с использованием агроспан 42 формировался оптимальный температурный режим, температура воздуха была выле на 2-5ㄷ, по сравнению с открытым грунтом. Данные биометрических измерений выявили преимущественное развитие растений салата под укрытиями, которое сохранялось на протяжении всего периода роста. Установлено, что применение временных укрытий из нетканого укрывного материала агроспан 42 обеспечило повыщение урожайности на 41, 7\%, по сравнению с контролем. Наибольщая урожайность 34,1 m/га получена на варианте с применением укрытий агроспан $42+$ мульча. Исследованиями по применению внекорневых подкормок растворами микроудобрений выявлено положстельное влияние на рост растений салата и формирование кочана. Урожайность на контрольном варианте (без обработки) составила 25,3 m/2а, на эталонном варианте (обработка мочевиной) - 26,8 m/2а. За годы исследований максимальная урожайность кочанов получена на варианте с применением внекорневых подкормок биоорганическим наноудобрением ЭкоФус (2 л/га), превышение относительно эталона составило 13,4\%, относительно контроля 20,2\%. Внекорневая обработка растений салата хелатным микроудобрением Силиплант позволила получить среднюю урожайность кочанов выше эталона на 12,7\% и выше контроля на 19,4\%. Содержание нитратов в кочанах по всем изучаемым вариантам было ниже предельно допустимой нормы 2000 мг/кг.

Ключевые слова: кочанный салат, укрывные материалы, ранняя продукция, внекорневая подкормка, микроудобрения, урожайность, качество.

\section{Sh. B. Bairambekov ${ }^{1}$, G. B. Gulyaeva' ${ }^{1}$ E. D. Gar'yanova', M. A. Dolgov ${ }^{2}$}

${ }^{1}$ All-Russian Research Institute of Irrigated Vegetable and Melon Growing,

${ }^{2}$ Branch of FGBU «Russian Agricultural Center» of Astrakhan region

vniiob-100@mail.ru

\section{INFLUENCE OF ELEMENTS OF CULTIVATION TECHNOLOGY OF CABBAGE LETTUCE IN ASTRAKHAN REGION ON YIELD AND QUALITY}

The cultivated area under the lettuce plants in the Astrakhan Region is insignificant, but there is a substantial potential for increasing the production of this crop. Actual point is the increase of gross yield of lettuce from open ground in the early period. The earliest harvest of high-quality products of cabbage lettuce can be obtained by planting seedlings under temporary covering from non-woven cover material. The conducted research showed that 
optimal temperature regime was formed under the temporary covering with using agrospan 42, the air temperature was higher on 2-5 oC comparing with the open ground. Biometric measurements revealed an advantageous development of lettuce plants under covering, which persisted throughout the whole growth period. It was established that the use of temporary covering from non-woven covering material agrospan 42 provided the increase in yield by $41,7 \%$ in comparison with the control variant. The highest yield of 34,1 t/ha was obtained on the variant with the use of agropan 42 coverings on arcs + mulching of soil. Studies on the application of foliar dressing with solutions of microfertilizers revealed a positive effect on the growth of lettuce plants and the formation of head. The yield on the control variant (without treatment) was 25,3 t/ha, on the reference variant (treatment with carbamide) - 26,8 t/ha. Over the years of research, the maximum yield of cabbage heads was received on the variant with the use of foliar fertilizing with bioorganic nanofertilizer EcoFus (2 l/ha), the excess comparing to the reference variant was 13,4\%, comparing to the control variant was $20,2 \%$. The foliar treatment of lettuce plants with chelate microfertilizer Silipant allowed to receive an average yield of heads which was above the reference variant by 12,7\% and the control variant - by 19,4\%. The nitrate content in cabbage heads for all studied variants was below the maximum permissible norm of $2000 \mathrm{mg} / \mathrm{kg}$.

Key words: cabbage lettuce, covering material, early ripening products, foliage application, microfertilizer, yield, quality.

\section{Опыт использования рассады картофеля при выращивании миниклубней в теплице}

\section{С. А. Корнацкий (к.с.-Х.н.), А. А. Попкова, А. Ж. Семенов}

Российский университет дружбы народов,

vitrolab@rambler.ru

Важным звеном в первичном семеноводстве картофеля является производство миниклубней, которое реализуется в особых условиях защищенного грунта. Существует несколько вариантов обеспечения процесса в зависимости от типа исходного материала и производственных условий. Это могут быть пробирочные растения, микроклубни или же безсубстратный способ с использованием аэрогидропонной установки. Все они имеют определенные недостатки, связанные с не всегда стабильной приживаемостью микрорастений при адаптации, высокой трудоемкостью при посадке в условиях теплицы, относительно слабую воспроизводимость результатов, физиологическую разнокачественность материала. Целью работь было улучшение посадочных характеристик микрорастений картофеля и разработка рассадного способа выращивания миниклубней картофеля с использованием торфотаблеток Jiffy 7. Показано, что использование хлорхолинхлорида (ССС) в составе питательной среды позволяет выращивать микрочеренки картофеля, пригодные для посадки непосредственно на торфотаблетки для адаптации. Нанесение ауксинсодержащей пасты на базальную часть микрорастений период адаптации к нестерильным условиям обеспечивало приживаемость растений близкую к 100\%. Высадка рассады в подготовленные горики в условиях теплищы заключалась в раскладывании торфотаблеток с растенияли в посадочные отверстия в субстрате и

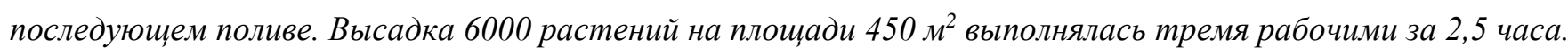
Начало активного роста у высаженных растений наблюдалось уже на 2-3 день после посадки. В 2016 г. при уборке сорта Ред Скарлет количество клубней/куст колебалось от 12 до 34 шт., средний вес клубня - от 13 до 37 г. По сорту Эстима эти показатели были соответственно: 5-14 шт. и 30-86 г. В 2017 г. те же 
показатели по сорту Ред Скарлет составили: 3-20 шт. и 20-38 г., по сорту Эстима - 6-18 и 14-74 2. Урожай первого полевого поколения после посадки в открытый грунт фракиии миниклубней (до 30 г, материал 2016 г.) составил в среднем 1,36 кг/куст или в пересчете 60 m/2a по сорту Ред Скарлет и по сорту Эстима, соответственно, 1,12 кг/куст или $49 \mathrm{~m} / 2$.

Ключевые слова: клональное микроразмножение, адаптаиия, микрорастения, микроклубни, миниклубни, торфотаблетки.

\section{S. A. Kornatskiy, A.A. Popkova, A.G. Semenov \\ Peoples’ Friendship University of Russia \\ vitrolab@rambler.ru}

\section{EXPERIENCE IN THE USE OF POTATO SEEDLINGS} FOR GROWING MINITUBERS IN GREENHOUSE

An important link in the primary seed production of potatoes is the production of minitubers, which is realized in special conditions of protected soil. There are several options to ensure the process, depending on the type of source material and production conditions. This can be test tube plants, microtubers or a non-substrate method using an aerohydroponics. All of them have certain drawbacks due to the not always stable survival of microplants during adaptation, the high labor input when planting in a greenhouse environment, the relatively weak reproducibility of results, and the physiological variability of the material. The aim of the work was to improve the planting characteristics of microplants of potatoes and to develop a seedling method for growing potato minitubers using Jiffy 7 peat pellets. It is shown that the use of chlorocholine chloride (CCC) in the nutrient medium allows growing potato micrografts suitable for planting directly on peat pellets for adaptation. The application of auxin-containing paste on the basal part of microplants, the adaptation period to non-sterile conditions, ensured the plant survival rate close to $100 \%$. Planting seedlings in pre-prepared pots under the conditions of the greenhouse consisted in spreading peat pellets with plants into the planting holes in the substrate and then watering. Planting 6000 plants on an area of 450 $\mathrm{m}^{2}$ was carried out by 3 workers in 2.5 hours. The beginning of active growth in planted plants was observed already 2-3 days after planting. In 2016, when harvesting the Red Scarlet variety, the number of tubers / shrub varied from 12 to 34, the average weight of the tuber was 13 to $37 \mathrm{~g}$. According to the Estima variety, these figures were respectively: 5-14 tubers and 30-86 g. In 2017, the same indicators for the variety of Red Scarlet were: 3-20 tubers and 20-38, according to the Estima variety - 6-18 and 14-74 g. The yield of the first field generation after planting in the open ground of the minitubers fraction (up to $30 \mathrm{~g}$, material of 2016) averaged $1.36 \mathrm{~kg} / \mathrm{bush}$ or in terms of $60 \mathrm{t} / \mathrm{ha}$ in the Red Scarlet class and Estima, respectively, $1.12 \mathrm{~kg} /$ bush or 49 t/ha.

Key words: clonal micropropagation, adaptation, microplantsmicrotubers, minitubers, peat pellets.

\section{Влияние сроков посева на урожайность лука репчатого}

М. Ю. Пучков (д.с.-х.н.), В. В. Зволинский, Е. Г. Локтионова (к.Х.н.)

Астраханский государственный университет,

rosecostroi@mail.ru

В Астраханской области, в последние годы, бурными темпами растёт производство репчатого лука.

Фермеры возделывают гибриды лука иностранной селекиии, в связи с этим определение сроков посева, для 
получения гарантированного урожай более $100 \mathrm{~m} / 2 \mathrm{a}$, и подбор наиболее адаптированных гибридов является актуальным и наиболее перспективным направлением исследования. Целью данной работы было изучение элементов технологии возделывания (срок посева, сорт, гибрид) лука репчатого для получения экологически чистой продукции. Опыты закладывались в 2011-2016 гг. на капельном оромении на полях базового хозяйства ВНИИООБ в Черноярском районе Астраханской области. Изучались современные гибриды $F_{1}$ лука фирмы Nunhems и Вејо, за стандарт был взят сорт селекиии Молдавского НИИСХ. В результате исследований было установлено, что масса луковищы зависела от количества образовавшихся листьев и срока посева. Наиболее высокий урожай был получен при посеве лука во второй декаде апреля независимо от года исследований. Урожайность гибридов фирмы Nuпhетs и Вејо превышала сорт Халиедон (стандарт) в 1,2-2,0 раза. Таку гибрида Пандеро F1 наибольшая урожайность достигла $180 \mathrm{~m} / 2 a$. У сорта Халиедон St общая урожайность составляла 70 m/2а, при товарной - 66 m/2а. Наибольший выход товарных луковии наблюдался у гибридов Комета $F_{1}(98,3 \%)$ и Утреро (98,4\%). Минимальное количество невызревших луковиц наблюдалось у гибридов Комета $F_{1}(0,7 \%)$, Валеро $F_{1}(0,8 \%)$ и Утреро $F_{1}(0,8 \%)$.

Ключевые слова: лук репка, сроки посева, сорт, гибрид $F_{1}$, урожайность, количество листьев, масса луковицьл.

\section{Yu. Puchkov, V. V. Zvolinsky, E. G. Loktionova}

\section{Astrakhan State University}

rosecostroi@mail.ru

\section{INFLUENCE OF SOWING DATE ON ALLIUM CEPA YIELD}

Onion production in Astrakhan region has been increasing rapidly in recent years. Local farmers cultivate foreign onion hybrids. Hence, determination of favorable sowing date to obtain onion yields over100 tons/ha, and selection of the most adapted hybrids is an actual and most promising research direction. The purpose of the study was to learn the elements of onion cultivation technology (sowing date, cultivar, hybrid) for producing environmentally friendly products. The experiments were carried out in drip irrigated fields of Research Institute of Irrigated Vegetable and Melon Growing (Chernoyarsky district of Astrakhan region) in 2011-2016. Modern $F_{1}$ hybrids of onion produced by Nunhems and Bejo were studied; Khaltsedon cultivar (Moldova) was a control. Bulb weight has been determined to depend on the number of leaves and the sowing date. The highest yield was obtained when onion sowing date was in the second decade of April, regardless of the research year. Yields of Nunhems and Bejo hybrids was 1.2-2.0 times higher compared to the control. The highest yield of Pandero $F_{1}$ hybrid reached 180 tons/ha. Khaltsedon total yield was 70.0 t/ha, and marketable yield - 66.0 t/ha. Cometa $F_{1}$ and Utrero $F_{1}$ had the greatest yield of marketable bulbs - 98.3\% and $98.4 \%$, respectively. Cometa $F_{1}$, Valero $F_{1}$ and Utrero $F_{1}$ hybrids had the minimum amount of unripe bulbs $-0.7 \%, 0.8 \%, 0.8 \%$, respectively.

Key words: Allium cepa, sowing date, variety, hybrid $F_{1}$, yield, number of leaves, bulb weight.

\section{Влияние биоприпаратов на продуктивность}

ярового ячменя в почвенно-климатических условиях Северного Прикаспия
Н. В. Тютюма (д.с.-х.н.), И. И. Климова, Н. А. Наумова,
В. А. Федорова (к.с.-Х.н.), Ю. П. Тарасенкова 
Прикаспийский НИИ аридного земледелия,

irina.ssd1981@yandex.ru

Производство зерна в любой стране мира создает экономическую базу для развития сельского хозяйства.

Повышение урожайности зерновых культур и улучшение качества получаемой продукции одна из основных задач растениеводства. Решение ее невозможно без освоения современных технологий возделывания сельскохозяйственных культур, неотъемлемой частью которых является применение биологических препаратов. Это направление приобретает все большую актуальность и, являясь одним из основных звеньев биологизации сельскохозяйственного производства, позволяет получать высокие, стабильные урожаи, обеспечивая при этом воспроизводство почвенного плодородия. Кроме того, перспективным является поиск и практическое использование новых микроорганизмов с полифункииональными свойствами, которые могут помочь растениям реализовать их потенциальную продуктивность и повысить их адаптивные свойства. Целью наших исследований являлось изучение влияния биологических препаратов на продуктивность растений и качество урожая ячменя в почвенно-климатических условиях Северного Прикаспия. В статье представлены результаты исследований влияние биопрепаратов (Флавобактерин, Агрофил, Ризоагрин, Штамм 8) на урожайность ярового ячменя в условиях Астраханской области за 2015-2017 г2. Полученные результаты показали, что биопрепараты при обработке семян способствовали улучшению всех показателей структуры урожсая, и почти на всех вариантах существенно повышалась урожайность. Из всех используемых в исследованиях биопрепаратов самыми эффективными при воздельвании ярового ячменя 8 почвенно-климатических условиях Северного Прикаспия были Флавобактерин и Штамм 8. При использовании Флавобактерина прибавка урожая относительно контроля на сорте Владимир составила 0,78 m/2а или 69,6\%. У сортов Консерто и Яромир на варианте с обработкой семян Штамм 8 прибавка урожсая составила 0,80-0,86 m/2а или 108,1-124,6\%, относительно контроля.

Ключевые слова: яровой ячмень, урожайность, биопрепараты, обработки, продуктивность, зерно, сорт.

\section{N. V. Tyutyuma, I. I. Klimova, N. A. Naumova, V. A. Fedorova, Yu. P. Tarasenko}

\section{Caspian Research Institute of Arid Agriculture}

irina.ssd1981@yandex.ru

\section{INFLUENCE OF BIOPREPARATIONS ON SPRING BARLEY YIELD IN NORTHERN CASPIAN REGION}

Grain production in any country is an economic base for agriculture development. Increasing yield of grain crops and improving product quality is one of the main objectives of crop production. It is impossible without modern technologies of crop cultivation, where biological agents are essential. Being one of the main links in biologization of agriculture, this direction is becoming increasingly important and allows receiving high, stable yields while ensuring soil fertility rehabilitation. In addition, search and practical use of new microorganisms with polyfunctional properties is promising, as they can help plants realize their potential productivity and increase adaptive properties. The purpose of the research was to study the effect of biological agents on plant productivity and quality of barley yield in Northern Caspian region. The article presents the results of studies on the effect of biological products (Flavobacterin, Agrophil, Rizoagrin, Shtamm 8) on spring barley yield in Astrakhan region in 2015-2017. The results obtained showed that seed treatment with biopreparations improved all yield structure parameters, and yield significantly increased in almost all variants. The most effective biopreparations used in studies were Flavobacterin 
and Shtamm 8. Flavobacterin treatment in 'Vladimir' cultivar plants increased spring barley yield by 0.78 t/ha (69.6\%) compared to the control. In cultivars 'Konserto' and 'Yaromir' treated with Shtamm 8 yield increasing was 0.80-0.86 tha (108.1-124.6\%) compared to the control.

Key words: spring barley, yield, biopreparations, treatment, productivity, grain, cultivar.

\section{Диагностика эритроцитарных нарущений при остром гепатите у собак}

\section{В. Д. Родионов, Ю. А. Ватников (д.вет.н.), И. Ф. Вилковыский (к.вет.н.)}

Российский университет дружбы народов ,

vatnikov_yua@pfur.ru

Острый гепатит - одно из тяжелых и частых заболеваний у собак, способных привести животное к гибели, болезнь часто встречается и составляет до $15 \%$ от всей возникающей патологии у собак. Это обстоятельство требует не только подробной клинической оценки самого состояния, но и понимания его патогенетических механизмов, что является важной основой для повышения эффективности лечения данной патологии. Несмотря на разработанные схемы лечения, осложнения и гибель собак на фоне острого гепатита это актуальная проблема ветеринарной медицины. Большое значение в ухудшении состояния собак при остром гепатите даже легкой степени тяжести имеют негативные изменения цитоархитектоники и агрегаџии эритроцичтов, которые, видимо, не обладают ярко выраженными видовыми и возрастными особенностями. Работа выполнена по материалам обследования 17 собак метисов с острым гепатитом легкой степени тяжести в возрасте 7-9 месящев. Пробы крови для исследования были взяты 8 первые сутки обращения с учетом данных анамнеза и клинических признаков. Пробы учитывали при подтверждении диагноза лабораторными исследованиями. В последующем животные получали необходимую коррекиию из состояния с помощью симптоматической и патогенетической терапии. Группа контроля представлена анализами крови пяти здоровых собак метисов в возрасте 7-9 мес. Установлено, что развитие клинической картины гепатита у собак, формирует выраженные негативные сдвиги в показателях эритроцитов. Структура эритроцитов подвергается значительной деформации, в их крови снижается количество дискоцитов и нормоцитов. Кроме того, у них в крови появляются эхиноцитты, шизоциты, большое количество мелких эритроцитарных агрегатов. Все это указывает, что даже легкий гепатит вызывает развитие сложной функциональной перестройки эритрона. Растет количество эритроцитов, имеющих тельиа Жолли. Появляется стойкое затруднения микроциркуляции, ухудщающее общее состояние и значительно снижающее резистентность животного, а, следовательно, затруднение перфузии капилляров и обмен веществ во всем организме.

Ключевые слова: собаки, гепатит, острое течение, эритрочиты, патология.

\section{D. Rodionov, Y. A. Vatnikov, I. F. Vilkovyskiy}

\section{Peoples`Friendship University of Russia}

vatnikov_yua@pfur.ru

\section{DIAGNOSTICS OF ERYTHROCYTE DAMAGE IN CANINE ACUTE HEPATITIS}

Acute hepatitis is one of the most serious and frequent diseases in dogs capable of leading an animal to death. The disease often occurs and accounts for up to 15\% of all the emerging pathology in dogs. This factor requires not only a 
detailed clinical evaluation of the condition, but also an understanding of its pathogenesis, which is an important basis for increasing the effectiveness of the disease treatment. Despite the developed treatment regimens, complications and death of dogs against the background of acute hepatitis is an urgent problem in veterinary medicine. Significant changes in the deterioration of dogs with acute hepatitis, even mild severity, have negative changes in cytoarchitecture and aggregation of erythrocytes, which apparently do not have pronounced species and age features. The work was carried out based on a survey of 17 metis dogs with acute mild hepatitis at the age of 7-9 months. Blood samples for the study were taken on the first day of treatment, taking into account the history and clinical signs. The samples were taken into account when confirming the diagnosis by laboratory tests. Subsequently, the animals received necessary correction from the condition with the help of symptomatic and pathogenetic therapy. The control group is represented by blood tests of 5 healthy dogs aged 7-9 months. It was established that development of the clinical picture of hepatitis in dogs, forms significant negative shifts in erythrocyte indices. The structure of erythrocytes undergoes considerable deformation, in their blood the number of discocytes and normocytes decreases. In addition, there are echinocytes, schizocytes, a large number of small erythrocyte aggregates in blood. All this indicates that even mild hepatitis causes the development of a complex erythron reconstitution. Number of red blood cells with Jolly's bodies increases. There is a persistent difficulty of microcirculation, worsening the general condition and significantly reducing the resistance of the animal and, consequently, the difficulty of perfusion of the capillaries and the metabolism throughout the body.

Key words: canine, hepatitis, acute stage, erythrocytes, pathology.

\section{Лечение гнойного эндометрита у собак}

Бинхун Ху, Ю. А. Ватников (д.вет.н.), Е. В. Куликов (к.б.н),

\section{И. А. Попова, О. А. Петрухина}

Российский университет дружбы народов ,

vatnikov_yua@pfur.ru

Гнойный эндометрит является одним из самых распространенных заболеваний собак. Несмотря на актуальность проблемы, многие вопросы диагностики, патогенеза, лечения и профилактики различных форм эндометрита собак остаются малоизученными. Особое внимание следует уделить неоперативным методам лечения эндометрита, которые позволяют не только сохранить репродуктивные функции породистых собак и кошек, но и избежать осложнений, связанных с развитием нейроэндокринных дисфункций после овариогистерэктомии. Цель. Предложить эффективный метод лечения животных с гнойным эндометритом. Исследования проводились на животных, которые после диагностики были разделены на три группь в зависимости от метода лечения. 1-й группе (8 собак): симптоматическая и патогенетическая терапия и обильное промывание матки раствором фурацилина. 2-я группа (4 собаки): симптоматическая и патогенетическая терапия без промывания. По настоянию владельщев 3 из 12 животных были пролечены хирургическим путем. Течение эндометрита у собак сопровождается ускорением СОЭ, лейкоиитозом, эритропенией, снижением концентрачии гемоглобина, гематокритом, иветным индексом крови, сдвигом ядра влево в лейкограмме. При лечении сук с гнойным эндометритом, метод симптоматической и патогенетической терапии и интенсивного промьввания матки раствором фурацилина, позволило остановить воспалительный прочесс в течение 7 дней, не прибегая к хирургическому вмешательству, что 
позволило сохранить репродуктивную функиию матки. Именно поэтому был разработан метод лечения гнойно-воспалительных процессов матки симптоматическим и патогенетическим методом и обильным промывванием матки раствором фурачилина. Предложенный комплексный метод лечения гнойного эндометрита с длительным интенсивным промыванием полости матки имеет значительные преимущества, так как позволяет сохранить репродуктивную способность животного.

Ключевые слова: гнойный эндометрит, собаки, анализы крови, метод, терапия.

\author{
Binhong Hu, Y. A. Vatnikov, E. D. Sotnikova, I. A. Popova \\ Peoples` Friendship University of Russia \\ vatnikov_yua@pfur.ru
}

\title{
TREATMENT OF CANINE PURULENT ENDOMETRITIS
}

Purulent endometritis is one of the most common dogs diseases. Despite the problem relevance, many diagnosis, pathology, treatment and prevention of various forms of dogs endometritis related issues remain poorly understood. Particular attention should be paid to non-operative methods for the endometritis treatment, which allow not only to preserve the reproductive functions of pedigree dogs and cats, but also to avoid complications associated with the neuroendocrine dysfunctions development after ovariohysterectomy. Offer an effective method of treating animals with purulent endometritis. The studies were carried out on animals, which after diagnosis were divided into three groups depending on the method of treatment. 1st group (8 dogs): symptomatic and pathogenetic therapy and abundant lavage of the uterus with a solution of furacilin. 2 nd group (4 dogs): symptomatic and pathogenetic therapy without rinsing. At the insistence of the owners, 3 specimens out of 12 were surgically treated. The course of the endometritis in dogs is accompanied by an acceleration of the ESR, leukocytosis, erythropenia, a decrease in the hemoglobin concentration, a hematocrit, a color blood index, and a shift of the nucleus to the left in the leukocyte formula. In the treatment of bitches with purulent endometritis with the method of symptomatic and pathogenetic therapy and extensive washing of the uterus with a solution of furatsilina allowed to stop the inflammatory process for 7 days without resorting to surgical intervention, which allowed to maintain the reproductive function of the uterus. That is why a method for treating purulent-inflammatory processes of the uterus with a symptomatic and pathogenetic method and abundant washing of the uterus with a solution of furacilin was developed. The proposed complex method of treatment of purulent endometritis with prolonged profuse washing of the uterine cavity in the postoperative period has significant advantages over the traditional one, since it allows to cure the animal.

Key words: purulent endometritis, canine, blood tests, method, therapy.

\section{Сравнительный анализ чувствительности возбудителя снежной плесени Microdochium Nivale к действующим веществам различных классов}

\section{К. А. Коледенкова, М. М. Романец, Е. В. Романова}

Российский университет дружбы народов,

ksenakoledenkova@mail.ru

Снежную плесень озимых зерновых вызывает фитопатогенный низкотемпературный гриб Місrоdochіuт nivale. Болезнь является одним из вредоносных заболеваний озимой пшениць во всех районах воздельввания озимых зерновых культур. Распространение болезни в посевах происходит за счет роста мицелия под 
снежным покровом или конидио- и аскоспорами, которые образуются на погибших растениях и переносятся на здоровые с ветром, дождем или насекомыми. Возбудитель болезни развивается, прежде всего, на переросших посевах при высокой влажности воздуха и температуре, близкой к точке замерзания. Особенно благоприятно для развития болезни длительное сохранение снежного покрова на непромерзмей почве. Симптомы проявляются в виде паутинистого налета белого или бледно-розового извета на загнивщих листьях и узле кущения. Спороношение патогена имеет вид мелких бледно-розовых или оранжевых подушечек у основания стеблей. На поверхности отмериих листьев образуются бледно-розовые или светло-оранжевье шарообразные плодовые тела диаметром 0,3 мм. При поражении данным патогеном можно наблюдать отмирание узла кущения, листовых влагалищ, корней и, следовательно, гибель всего растения. Не полностью пораженные растения отстают в развитии, зерно в их колосьях часто формируется неполноценныл. Вредоносность снежной плесени заключается в изреживании посевов, зачастую и полной их гибели. В лабораторных условиях была оченена чувствительность штамма из коллекиии Ботанического сада (2. Москва) к действующим вещуествам различного химического происхождения. В результате проведённого сравнительного анализа интенсивности подавления роста фитопатогена выявлено, что подавлению роста гриба Microdochium nivale на 83,2-100\% способствуют действующче вещества карбендазим, беномил и прохлораз. Полученные результаты могут служить обоснованием в выборе эффективного протравителя для защиты зерновых культур от приобретающего всё большую вредоносность заболевания либо разработки нового препарата для сельского хозяйства.

Ключевые слова: снежная плесень, фунгиџиды, химические препараты, протравители, действующее вещзество, фунгицидный скрининг, фитопатоген, Microdochium nivale, M. nivale, Fusarium.

\section{K. A. Koledenkova, M. M. Romanets, E. V. Romanova}

Peoples`Friendship University of Russia, ksenakoledenkova@mail.ru

\section{COMPARATIVE SENSITIVITY ANALYSIS OF MICRODOCHIUM NIVALE TO VARIOUS ACTIVE INGREDIENTS}

Phytopathogenic low-temperature fungus Microdochium nivale causes pink snow mold of winter cereals. The disease is one of harmful diseases of winter wheat in all areas of winter crop cultivation. Spread of the disease in crops is due to mycelium growth under snow cover, conidia and ascospores are formed on dead plant residues and transferred to healthy ones by wind, rain or insects. Causative agent of the disease develops on overgrown crops at high humidity and cold temperature close to freezing point. Long-term presence of snow cover on unfrozen soil is especially favorable for disease development. Symptoms are white or pale pink cobwebs on decaying leaves and stem nodes. Spore pathogen has appearance of small pale pink or orange pads at the base of stems. Pale pink or light orange spherical fruit bodies with a diameter of $0.3 \mathrm{~mm}$ are formed on surface of dead leaves. The pathogen affects nodes, leaf sheaths and roots which can result in death of the whole plant. Partially affected plants develop poorly, grain in the ears often forms defective. Sensitivity of the strain from the collection of Botanical Garden (Moscow) to various chemical active substances was estimated in laboratory. According to results obtained active substances carbendazim, benomyl and prochlorase inhibit fungus growth by 83.2-100\%. Therefore, an effective disinfectant for cereal protection or a new preparation can be developed based on the data.

Key words: snow mold, fungicides, chemicals, seed treatment, seed dressers, active ingridient, chemical screening, sensitivity, plant pathogen, Microdochium nivale, M. nivale, Fusarium. 
Разработка новых методов ландиафтной архитектуры и концепция их интеграции в туристические марируты, на примере водных марирутов г. Санкт-Петербург

\section{И. Н. Воробьева, Е. Ю. Зайкова}

Российский университет дружбы народов ,

lena_landscape21@mail.ru

В современном мире остро стоит вопрос организации туристических маршрутов в городах, имеющих статус культурного наследия. Во всем мире тенденция сохранения природных территорий набирает темп. Даже в условиях сильной урбанизащии, города должны максимально поддерживать нормальную экологическую ситуацию за счёт сохранения природных территорий и современных технологий ландшафтной архитектуры. На данный момент городское развитие мегаполисов России нацелено на организаџию доступного жилья, развитие инфраструктуры и сохранение существующих зеленьх массивов. Однако, остро стоит вопрос улучшение ситуации на незадействованных людьми территориях, являющихся культурным наследием. Например, в городе Санкт - Петербург существует большое количество парков и скверов, находящихся в хорошем состоянии, за которыми осуществляется ежедневньй уход. Городежегодно посещуает большое количество туристов. В данной статье рассмотрены новые подходы к организации туристических маршрутов на воде с включением многочисленных фортов и островов Финского залива. Онидолжны работать на восстановление и задействование природного ландиафта, сохранение его идентичности и обеспечения устойчивого развитие территорий. Интеграция природной составляющей на угнетенных территориях, внедрение универсальных моделей ландшафтной архитектуры и адаптация территорий для людей разного возраста и социального статуса позволит создать гармонично развивающчеся моделирассматриваемых ландшафтныхучастков, востребованные и жителями, и туристами. Целью данной работы является реорганизаџия сущуествующчих водных туристических маршрутов города и анализ типологической структуры фортов для предложений их последующего современного использования за счёт интегращчи разработанных универсальных моделей ландщафтного преобразования.

Ключевые слова: ландшафтное наследие ЮНЕСКО, типологическая структура островов, ландшафтные модели, реорганизация туристических марирутов, устойчивое развитие фортов, идентичный ландиафт, сохранение природного биотопа.

\section{N. Vorobeva, E. Y. Zaykova}

Peoples`Friendship University of Russia, lena_landscape21@mail.ru

\section{NEW METHODS OF LANDSCAPE ARCHITECTURE DEVELOPMENT AND THE CONCEPT OF THEIR INTEGRATION INTO TOURIST ROUTES, USING THE EXAMPLE OF WATER ROUTES IN ST. PETERSBURG}

In the modern world, the issue of tourist routes organization in cities with the status of cultural heritage is really acute. Often, the organization of tourist routes is reduced solely to material benefits without accent on the natural landscape, and sometimes even exterminating it. All over the world, the trend of natural areas conservation is picking up pace]. Even in conditions of strong urbanization, cities should maintain a normal ecological situation to its maximum by conserving natural areas and modern technologies of landscape architecture. At the moment, the urban development 
of mega-cities of Russia is aimed at the organization of affordable housing, infrastructure development and conservation of existing green areas (sanctuaries, protected areas, etc.). However, the acute issue is the improvement of the situation on territories that are not used by people, which are cultural heritage. For example, in the city of St. Petersburg there is a large number of parks and squares in good condition, and they are maintained on a daily basis. The city has a large number of cultural heritage sites under the protection of UNESCO, so it is visited annually by a large number of tourists. City provides all conditions for convenient accommodation, infrastructure, as well as various tourist routes, however not all of them reflect the landscape feature of the city.This article considers new approaches to the organization of tourist routes on the water with the inclusion of numerous forts and islands of the Gulf of Finland. They must work to restore and use the natural landscape, preserve its identity and ensure the sustainable development of territories. Integration of the natural component in the oppressed areas, the introduction of universal models of landscape architecture and the adaptation of territories for people of different ages and social status will allow the creation of harmoniously developing models of the considered landscapes, that will be in demand for residents and tourists.

Key words: UNESCO landscape heritage, typological structure of islands, landscape models, reorganization of tourist routes, sustainable development of forts, identical landscape, conservation of natural biotope.

\section{Экспортоориентированное импортозамещение в пищевой промышленности как элемент углубления интеграции в рамках ЕАЭС}

\section{В. Ю. Чернова (к.э.н.)}

Российский университет дружбы народов, veronika_urievna@mail.ru

ЕАЭС являясь крупнейшим интеграционным объединением и изначально обладающее рядом преимуществ, тем не менее, испытывает сложности. В статье на основе статистических данных Федеральной службы государственной статистики, Федеральной таможенной службы РФ, Всемирного банка, Евразийского банка развития, аналитических материалов и публикуемых отчетов Центра интеграционных исследований ЕАБР произведена оченка уровня интеграџии стран-членов ЕАЭС, выявлены интеграционные и дезинтеграционные тренды, проблемы внешнего и внутреннего характера, препятствующие укреплению партнёрских отношений. Проанализированы меры государственной поддержки, направленные на решение указанных проблем. Методологические аспекты исследования реализуются посредством использования системного и комплексного подхода, логического метода, сравнительного и ситуационного анализа. Эффекты интеграции иницируют разнонаправленные тренды во взаимной торговле. На сокращение взаимной торговли существенное влияние оказал кризис в России, имеющей самую больщую экономику среди стран-участнии и обеспечивающей самый высокий уровень участия в товарообороте. В тоже время ЕАЭС в определенной степени играет роль амортизатора негативного влияния внешних шоков. Причинами снижения торговли стран-членов ЕАЭС весьма различны, среди основных из них ценовой фактор, замедление темпов роста мировой экономики; сохранение и продление режима санкций и ответных мер России; снижение курсов начиональных валют к доллару США. В исследовании показаны возможности и направления углубления интегращии на основе российского экспортоориентированного импортозамещения в агропромышленном комплексе. Сделан вывод о наличии новых возможности для применения интеграционных 
инструментов. Одним из важнейших направлений углубления интеграции стран-членов ЕАЭС должна стать политика экспортоориентированного импортозамещения. Такая политика должна предусматривать дальнейшее стимулирование собственного производства, глубокую переработку сельскохозяйственного сырья, оптимизацию сущеествующих цуепочек добавленной стоимости и организацию новых, обеспечение конкурентоспособности сельскохозяйственной продукции и продукции пищевой промымленности за счет повышения качества продукции, развитие сотрудничества и коопераџии в сфере АПК.

Ключевые слова: интеграция, евразийский экономический союз, экспортоориентированое импортозамещуение, агропромышленный комплекс, пищевая промышленность.

\section{Yu. Chernova}

\section{Peoples`Friendship University of Russia}

veronika_urievna@mail.ru

\section{EXPORT-ORIENTED IMPORT SUBSTITUTION IN FOOD INDUSTRY AS AN ELEMENT OF DEEPENING EURASIAN ECONOMIC INTEGRATION}

The Eurasian Economic Union (EEN) is the largest association having a number of advantages, nevertheless, it experiences some difficulties. We used statistical data of Federal State Statistics Service (Rosstat), Federal Customs Service of the Russian Federation, the World Bank, the Eurasian Development Bank (EDB), analytical articles and published reports of the EDB Center for Integration Studies in the research. As a result, we assessed integration level of the EEU countries, detected integration and disintegration trends, external and internal problems, which impede partnership strengthening, and analyzed government support aimed at solving these problems. Reduction of EEN trade was resulted from the crisis in Russia, which has the largest economy among the participating countries and which provides the highest level of participation in trade. At the same time, the EEN is an absorber of negative impact of external shocks. Reasons for trade decline are very different, but the main ones are: price factor, world economy slowdown, sanctions extension and retaliatory measures of Russia, easing of the rate of Russian ruble to US dollar. The study shows the opportunities and directions for deepening integration based on Russian export-oriented import substitution in the agro-industrial complex. Such a policy should provide for further stimulation of own private production, processing of agricultural raw materials, optimization of existing value chains and organization of new ones, ensuring competitiveness of agricultural and food products through improving product quality and cooperation development in the agro-industrial complex.

Key words: integration, Eurasian economic union, export-oriented import substitution, agro-industrial complex, food industry.

\section{Типологизация субъектов малого бизнеса в сельском хозяйстве}

\section{А. З. Улимбашев}

Санкт-Петербургский государственный аграрный университет, ulimbashev_a@inbox.ru

Мальй агробизнес имеет высокую значимость для решения проблем развития агропромышленного комплекса и сельской местности, что определяет необходимость поиска альтернативных, сравнительно более эффективных, способов регулирования и поддержки деятельности субъектов малого агробизнеса. Статья 
посвящена представлению концеетуальной схемы типологизацчи субъектов малого агробизнеса предпринимателей-собственников, на основании различия в их структуре мотивов деятельности, как базы для дальнейших разработок мотивационных механизмов регулирования малого агробизнеса. Анализ мотивации субъектов малого агробизнеса проводится на базе конщепџии личных издержек (ЛИ), определяющзая ЛИ как любые препятствия на пути преследования интересов человека. Основанием представляемой типологии является суждение, что два респондента похожи, однотипны, если у них в сравнительно большей степени совпадает структура определяюших мотивов предпринимательской деятельности, в противном случае они несхожи, разнотипны. Реализуется нисходящая стратегия типологического анализа. В рамках типологического анализа осуществляется попьтка проведения многомерной классификации (группировки) с использованием данных измеренных в порядковой (ранговой) шкале. В целом, доказывается наличие в сельском хозяйстве пяти типов предпринимателей-собственников, имеющих различные базовые устремления (мотиваторы), как следствие разную структуру мотивов деятельности, различный предпринимательский потенциал, и пригодных для решения различных проблем развития АПК и сельской местности.

Ключевые слова: мальй бизнес, сельское хозяйство, регулирование, типология.

\author{
A. Z. Ulimbashev \\ St. Petersburg State Agrarian University \\ ulimbashev_a@inbox.ru
}

\title{
TYPOLOGIZATION OF SMALL BUSINESSES IN AGRICULTURE
}

Small agricultural businesses have a high significance for solving development problems in agro-industrial complex and rural areas. It needs to search for alternative, relatively more effective ways of regulating and supporting small agribusinesses. The article is devoted to the conceptualization of typologization of small agribusiness subjects (entrepreneurial owners) depending on differences in their activity motives, as a basis for further development of motivational mechanisms for regulation of small agribusiness. An analysis of motivation of small agribusinesses is carried out on the basis of the personal expences (PE) concept. The basis of the typology being presented is the judgment that two respondents are similar and of the same type if they have a relatively similar structure of determining motives for entrepreneurial activity, otherwise they are dissimilar and diverse. A downward strategy of typological analysis is being implemented. Within the framework of typological analysis, an attempt is made to conduct multidimensional classification (grouping) using the data measured in the ordinal (rank) scale. In general, it is proved that there are five types of entrepreneurial owners in agriculture having different basic aspirations (motivators), resulted in different structure of activity motives, different entrepreneurial potential, and various problems of agro-industrial complex and rural areas development to be solved.

Key words: small businesses, agriculture, regulation, typology. 


\section{Гринсон Годдэй Нгерибо, Илебери Вариеби}

Российский университет дружбы народов,

greensonkit@yahoo.com

В современных экономических условиях в большинстве стран мира аграрный сектор представляет собой самую нестабильную отрасль. На его развитие оказывают влияние как внутренние, так и внешние факторы. Особенно это актуально для Нигерии, где трудится более 60\% населения станы. В стране наблюдается нехватка продовольствия как в городах, так и в сельской местности. Основной целью исследования является выявление и систематизащия основных факторов, оказывающих влияние на сельскохозяйственное производство не только Нигерии, но и других стран. Авторы выделяют такие из них как: влияние ценообразования, развитие монопсонического рынка, получение низкого дохода фермерами. Одними из ключевых проблем с которыми сталкивается сельское хозяйство любой страны и рассматриваемые в статье являются экологические издержки, связанные с интенсификацией сельскохозяйственного производства. На основе проведенного анализа авторы пытаются найти пути минимизации отрищательного влияния этих факторов. Авторами предлагаются следующие пути решения.Во-первых, необходимо государственное вмешательство в экономику. Необходимо провести аграрную реформу в стране. Необходимо наладить связь между местными, региональными и национальными общественными организациями для привлечения внимания к проблемам фермерских хозяйств. Во-вторых, необходимо минимизировать цены, через введение субсидий, это подстегнет как спрос, так и предложение на рынке. $B$ третьих, введение тарифов. Что оградит внутренний рынок страны от импорта и тем самым также позволит развиваться местному производству. В-четвертых, сельское хозяйство может также являться источником капитала, необходимого для развития промышленности в тех масштабах, которые требуются для получения излишков. Предложенные методы могут применяться как отдельно, так и комплексно.

Ключевые слова: сельское хозяйство, развитие сельскохозяйственного сектора, цены на сельскохозяйственных рынках, стагнация сельскохозяйственного сектора, функиионирование кооперативной системь.

\section{Greenson Godday Ngeribo, Ileberi Variebi}

\section{Peoples`Friendship University of Russia}

greensonkit@yahoo.com

\section{CONTEMPORARY PROBLEMS IN AGRARIAN ECONOMY}

In the current economic conditions in most countries of the world the agrarian sector is the most volatile sector. Its development is influenced by both internal and external factors. This is especially true for Nigeria, where more than $60 \%$ of the country's population works. There is a food shortage in the country, both in cities and in rural areas. The main objective of the study was to identify and systematize the main factors affecting agricultural production not only in Nigeria but also in other countries. We distinguish the following factors: pricing influence, monopsonic market development, farmers' low income. Key problems faced by agriculture in any country are environmental costs associated with intensification of agricultural production. Based on the analysis, we try to find ways to minimize the negative impact of these factors and suggest the following solutions. On the first hand, government intervention in the economy is needed, it is necessary to carry out agrarian reform, to establish links between local, regional and national public organizations to draw attention to farming problems. On the second hand, it is necessary to minimize 
prices through subsidies; this will increase both supply and demand in the market. Moreover, tariffs setting will protect domestic market of the country from imports and, thus, will also allow local production to develop. Agriculture can also be a source of fund necessary for industry development. The methods proposed can be used singly or in combination.

Key words: agriculture, development of agricultural sector, prices in agricultural markets, stagnation of agricultural sector, functioning of cooperative system.

\section{Разработка новых методов биотехникивоспроизводства рыб на основе анализа механизмов нейроэндокринной регуляции их размножения}

П. Е. Гарлов (д.б.н.), Н. Б. Рыбалова (к.с.-х.н.), Т. А. Нечаева (к.б.н.), С. У. Темирова (к.б.н.), Е. Д. Шинкаревич (к.с.-х.н.), Б. С. Бугримов

Санкт-Петербургский государственный аграрный университет, garlov@mail.ru

Основой управления процессами размножения и выращивания рыб является анализ механизмов гипоталамической нейроэндокринной регулящии, осуществляемой гипоталамо-гипофизарной нейросекреторной системой (ГГНС). Актуальной рыбохозяйственной задачей является восстановление численности природных популяций ценных видов рыб путем повышения эффективности их искусственного воспроизводства. Целью исследования является разработка новых методом биотехники их воспроизводства на основе анализа механизмов участия ГГНС в осуществлении нереста. Для этого с кониа 1970-х г2. и по настоящее время выполнялось полносистемное эколого-гистофизиологическое и экспериментальное исследование ГГНС в этом плане. Установлено, что нонапептидные нейрогормоны ГГНС иниииируют нерест, затем способствуют овуляции и спермиации. К завершению нереста они участвуют в адаптациях организма, направленных на преодоление физиологического стресса путем поддержания метаболического равновесия организма. На основе представлении о важной ключевой роли ГГНС в интеграции нереста, осуществляемой по принципу саморегуляции, разработаны конструктивные рабочие схемы и, в итоге, система управления размножением рыб. Конкретно, для стимуляции созревания производителей рыб был разработан и внедрен в осетроводство препарат изолированной передней доли гипофиза, а также способ стимуляции созревания самщов его изолированной задней долей. Это позволило повысить безотходно степень рыбоводного использования производителей в среднем на 15\%. Для задержки созревания производителей рыб разработан эффективный способ их промышленного резервирования в среде критической солености 4-8\%. Для заводского воспроизводства природных популячий осетровых и лососевых рыб разработаны новые методы биотехники управления их воспроизводством триадой ведущих экологических факторов сигнального (температуры и освещенности) и филогенетического значения (критической солености). Проведены производственные испытания эффективности новой и стандартной биотехники воспроизводства осетровых и лососевых рыб. Обсуждаются их рыбоводно-биологические результаты. Разработанные новые методы биотехники управления воспроизводством применимы для внесезонного рыбоводства как в рыбохозяйственной, так и в природооохранной областях.

Ключевые слова: гипоталамо-гипофизарная нейросекреторная система рыб, нейроэндокринная регуляиия размножения рыб, биотехника разведения рыб, заводское воспроизводство популяций рыб. 
P. E. Garlov, N. B. Rybalova, T. A. Nechaeva, S. U. Temirova,

E. D. Shinkarevich, B. S. Bugrimov

Saint-Petersburg State Agrarian University

garlov@mail.ru

\section{NEUROENDOCRINE REGULATION OF BREEDING}

AND NEW METHODS OF FISH REPRODUCTION

Analysis of hypothalamic neuroendocrine regulation mechanisms carried out by hypothalamo-hypophysial neurosecretory system (HHNS) is the basis of fish reproduction and cultivation management. The main topical fisheries challenge is restoration the number of valuable fish natural populations through improving artificial reproduction. The aim of the study was to develop a new biotech method for fish reproduction based on the analysis of HHNS participation mechanisms in spawning. Hence, ecological-histophysiological and experimental research of HHNS has done since the '1970s. It is established that nonapeptide neurohormones of HHNS initiate spawning, promote ovulation and sperm release. Near spawning completion they participate in adaptation to overcome physiological stress by maintaining body metabolic equilibrium. Constructive working schemes and fish reproduction management system were, eventually, developed on the basis of the discovery an important key role of HHNS in integration of spawning by self-regulation principle. Methods to stimulate sex maturity of fish breeders and males maturing by means of isolated anterior and posterior hypophysial lobes preparations were developed and introduced in sturgeon culture, specifically. Thus, degree of breeders usage was improved to an average of $15 \%$. An effective method to delay maturation - reserving in solution with critical salinity 4-8\% - was developed. New methods of biotech control for factory reproduction of sturgeon and salmonid populations by means of the leading ecological factors (temperature, photoperiod, critical salinity) were developed. New bioengineering methods are intended for a year-round fish reproduction in both fisheries and nature conservancy fields.

Key words: hypothalamo-hypophysial neurosecretory system in fish, neuroendocrine regulation of fish reproduction, biotech of fish breeding, factory reproduction of fish populations. 